\title{
The effect of tree age on the chemical composition of the wood of silver birch (Betula pendula Roth.) in Poland
}

\author{
Hubert Lachowicz ${ }^{1} \cdot$ Hanna Wróblewska ${ }^{2} \cdot$ Rafał Wojtan $^{3} \cdot$ Magdalena Sajdak $^{2}$
}

Received: 15 October 2018 / Published online: 24 September 2019

(c) The Author(s) 2019

\begin{abstract}
The article presents the results of a so far most extensive study on the effect of tree age on variation of the chemical structure of silver birch wood carried out in Poland. Field studies took place in 12 forestry districts distributed throughout the country. In each district, study sites were selected with stands aged approximately 30, 50, and 70 years in fresh broadleaved forest habitats, as well as in five districts in fresh mixed broadleaved forest habitats. Analyses were made of the contents of substances soluble in cold and hot water, ethanol and $1 \% \mathrm{NaOH}$, as well as the contents of cellulose, lignin, pentosans and ash, and the $\mathrm{pH}$, of wood from 306 silver birch trees. Tree age was shown to have a significant effect on the contents of cellulose, pentosans, ash, and substances soluble in $1 \% \mathrm{NaOH}$. In the case of the other characteristics, age was found to have no significant effect. The cellulose content was lowest in 30-year-old stands and increased with tree age. Similar observations were made regarding ash content. Contents of pentosans and substances soluble in $1 \% \mathrm{NaOH}$ were highest in the wood of the youngest trees. Since birch wood is used by the pulp and paper, board and energy industries, the knowledge of its chemical composition, depending on the age of the trees, can be of potential practical importance for its further application.
\end{abstract}

\footnotetext{
Magdalena Sajdak

m_sajdak@itd.poznan.pl

Hubert Lachowicz

hubert.lachowicz@wl.sggw.pl

Hanna Wróblewska

h_wroblewska@itd.poznan.pl

Rafał Wojtan

rwojtan@wl.sggw.pl
}

1 Department of Forest Utilization, Warsaw University of Life Sciences (SGGW),

Nowoursynowska Str 159, 02-776 Warsaw, Poland

2 ŁUKASIEWICZ Research Network - Wood Technology Institute, Winiarska Str 1, 60-654 Poznan, Poland

3 Laboratory of Dendrometry and Forest Productivity, Warsaw University of Life Sciences (SGGW), Nowoursynowska Str 159, 02-776 Warsaw, Poland 


\section{Introduction}

Wood is one of the main sources of feedstock for the production of pulp and paper, boards and furniture, as well as increasingly popular biorefinery products (biochemicals, biomaterials, biofuels, and others). The currently growing market demand for naturally derived compounds and the need to replace synthetic ones have led to the increasingly efficient utilisation of wood (reuse, recycling, recovery), as well as increasing interest in studying the individual chemical components of wood and identifying novel application pathways and value-added solutions for particular bioactive molecules (Pietarinen et al. 2006; Roitto et al. 2015; Routa et al. 2017; Royer et al. 2012).

The structural compounds of wood are natural biopolymers such as cellulose, hemicellulose (carbohydrates), and lignin, which together account for 90-95\% of the mass of absolutely dry wood. The remaining 5-10\% consists of nonstructural components such as mineral substances, substances soluble in organic solvent (extractives) and water (Prosiński 1984). Cellulose is a linear carbohydrate with a crystal structure. Hemicelluloses are noncellulosic carbohydrates that differ from cellulose in their composition and structure. Softwood hemicellulose consists of pentosans and hexosans, but hardwood hemicellulose consists mainly of pentosans. Lignin is an amorphous polymer with a complex structure, mainly consisting of three phenylpropane monomers: p-hydroxyphenyl, guaiacyl and syringyl. The extractives consist of fats, fatty acids, resins, resin acids, terpenes, waxes, alcohols, phenols, steroids, wood gums, etc. The composition and amount of extractives depend on the solvent used (e.g. ethanol-benzene mixture, ethanol, acetone, dichloromethane, and ethyl ether). The ethanol-benzene mixture gives the highest level of wood extractives, but because of the high toxicity of benzene, other solvents like acetone and ethanol are commonly used. Substances soluble in cold and hot water include mineral salts, sugars, tannins, dyes, pectins, free acids, and others (Fengel and Wegener 1989; Han and Rowell 1997; Prosiński 1984).

The proportions of particular components in wood tissue depend on the species, the habitat conditions, the climate, the part of the tree from which samples are taken (trunk, branches, roots, sapwood or heartwood, bark, juvenile, or mature wood), the time of year, and the health of the tree (Bikovens et al. 2013; Miranda et al. 2017; Szczepkowski et al. 2007; Zobel and Sprague 1998). Another factor for the variation of the chemical structure of wood and its possible uses is the age of the tree, as has been documented for certain species (Berrocal et al. 2004; Fidelis et al. 2013; Healey et al. 2016; Miranda and Pereira 2002; Rencoret et al. 2011; Uprichard and Lloyd 1980). However, these studies have not included the silver birch (Betula pendula Roth.), which is one of the dominant broadleaf species in Poland, accounting for 669,000 ha of Polish forests (GUS 2017).

The relationship between tree age and the properties of wood has long been a topic of interest to many researchers. Efforts have been made to explain the mechanical properties of wood with reference to its anatomical and chemical structures, which change as trees grow and mature. Research has been carried out to determine the age at which trees should be felled so that their wood is of 
suitable quality for the use in construction, industry or energy production, and currently also for biotechnological applications (Karnaouri et al. 2016; Morais and Pereira 2012; Prosiński 1954; Stolarski et al. 2011; Testova et al. 2009; Uprichard and Lloyd 1980).

The results of the studies on the chemical composition of silver birch wood may be found in a number of publications (Fabisiak 2005; Fengel and Grosser 1975; Galewski and Korzeniowski 1958; Helińska-Raczkowska and Fabisiak 1995; Nikitin 1962; Nurmi 1997; Surmiński 1964; Tullus et al. 2014; Wagenführ and Scheiber 2007; Wanin 1953; Voipio and Laakso 1992). However, a significant number of these studies are based on a small number of samples, often of undocumented origin. In view of the growing economic importance of birch wood in Poland, studies on its physical, mechanical, structural, and fuel properties were carried out, which showed that most of the studied parameters are significantly affected by location, habitat, age, and tree thickness (Lachowicz 2010a, b, 2011a, b, 2015; Lachowicz and Paschalis-Jakubowicz 2011; Lachowicz et al. 2018a, b, 2019a). The influence of tree stand location and the forest habitat type on the chemical composition of birch wood was also previously studied by Lachowicz et al. (2019b). The results of this research showed a statistically significant influence of stand location on all investigated components of the chemical structure of birch wood. On the other hand, no statistically significant influence of the forest habitat type on the chemical composition of birch wood was found.

The aim of this study was to analyse the influence of the age factor on the content of selected chemical components of silver birch wood in Poland. Currently in Poland as well as in Europe there is strong competition between the pulp and paper, fibreand chipboard industries, and the energy industry, which is increasing its demand for wood as a renewable energy source (Hytönen and Nurmi 2015; Nurmi 1997). Therefore, knowledge of the influence of tree age on the chemical composition of wood may have important practical significance from the point of view of rational management and use of wood for particular branches of industry. The results of this study may also serve as a knowledge base for identifying suitable naturally derived compounds for biorefinery products or for other future industrial applications.

\section{Materials and methods}

\section{Study sites}

The research was carried out on tree stands belonging to the Polish State Forests. Samples were taken from birch trees aged approximately 30, 50, and 70 years, growing in habitat types classified as fresh broadleaved forest (FBF) and fresh mixed broadleaved forest (FMBF). In these two habitat types, birch stands are dominant in Poland in terms of both area covered and wood volume. The studies were carried out in 12 forestry districts distributed throughout the country. Figure 1 shows the locations of the forestry districts where study sites were established, and the country's main growing areas of silver birch. 


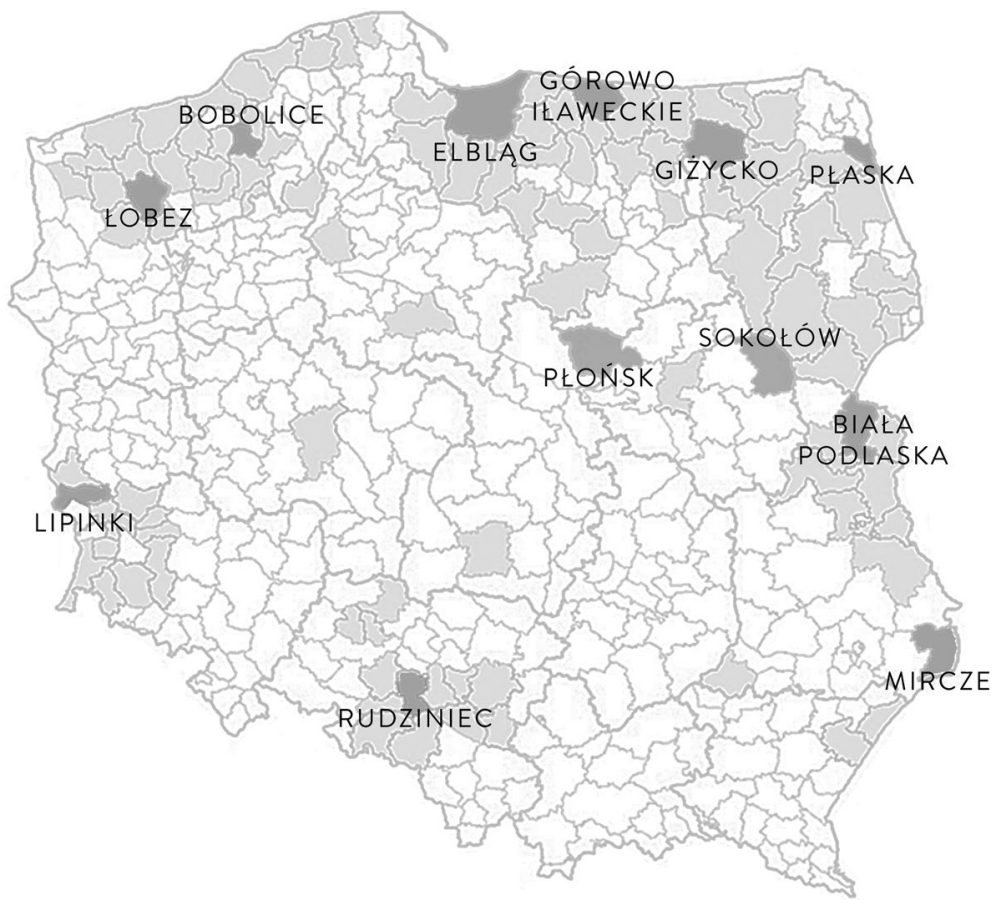

Fig. 1 Locations of study sites and main growing areas of silver birch in Poland. Dark grey areas-location of forestry districts where the study sites were established; light grey areas-forestry districts in which the area of tree stands with birch as the dominant species exceeds 1000 ha

\section{Sampling and analysis}

To select trees for analysis, the breast height diameters of all trees on the study sites were measured (Wolski 1969). The sample trees were selected from those whose diameter exceeded $7 \mathrm{~cm}$, using Hartig's method, which is based on the average breast height cross section. According to Hartig's method, trees on a sample plot are arranged in such a way that all diameter groups have equal total basal areas. Next, an equal number of test trees is assigned to a particular diameter group. In this study, the average breast height cross section of the measured trees was assigned to the three thickness classes: class 1 -the thinnest trees; class 2-trees of moderate thickness; and class 3-the thickest trees (Graves 1906; Grochowski 1973).

From each study site, six trees-two from each thickness class-were selected and felled. In total, material for analysis was taken from 306 trees. From each felled tree, two or three round timber sections were taken, each of length $50 \mathrm{~cm}$. Starting from breast height $(130 \mathrm{~cm})$, one section was cut from the trunk in a downward direction, and one or two sections in an upward direction (towards the crown). These sections were then cut into split $\log$ s and labelled with appropriate descriptions, which allowed for their identification in further stages of the study. Next, the wood was debarked and split open in order to increase the uniformity of drying. Wood from the internal part of the split log was cut out such that the test samples could be 
obtained from the outer part of the trunk (mature wood). At the same time, the material was sorted to obtain healthy wood without defects such as knots, construction defects, colouring, insect or fungal infections and without reaction wood.

The split logs were stacked and seasoned outdoors under shelter in natural conditions from September to March until the MC was about 15\%. The wood was then prepared for analysis in accordance with applicable standards. Samples with dimensions of $20 \times 20 \times 30 \mathrm{~mm}$ were cut out from the internal part of the split logs of all 306 test trees. Next, the material from each study site (six trees representing all thickness classes) was ground in a Pulverisette 15 cutting mill (Fritsch, Germany) and sieved to the required granularity: $0.5-1.0 \mathrm{~mm}$ for the chemical analysis, and $0.25-0.5 \mathrm{~mm}$ for $\mathrm{pH}$ determination using an Analysette 18 analytical sieve shaker (Fritsch, Germany) in order to obtain 51 homogeneous lots, from which random samples for analysis were taken. A more extensive description of the sampling procedure can be found in other papers (Lachowicz et al. 2018a, b, 2019a, b).

The chemical composition was determined in 51 samples of birch wood. These were labelled with numbers denoting the district and habitat type, from 1 to 17 (1 Płońsk FBF, 2 Sokołów FBF, 3 Biała Podlaska FBF, 4 Płaska FBF, 5 Giżycko FBF, 6 Giżycko FMBF, 7 Górowo Iławeckie FBF, 8 Elbląg FBF, 9 Mircze FBF, 10 Bobolice FBF, 11 Bobolice FMBF, 12 Łobez FBF, 13 Łobez FMBF, 14 Lipinki FBF, 15 Lipinki FMBF, 16 Rudziniec FBF, and 17 Rudziniec FMBF) and with numbers denoting the tree age: $70(66-72)$ years, 50 (40-53) years, and 30 (26-33) years.

In the birch wood, the content of main components like lignin and carbohydrates (cellulose, hemicelluloses) together with mineral substances (ash) and extractives (substances soluble in cold and hot water and in ethanol) as well as $\mathrm{pH}$ value was determined by classical methods (Browning 1967; Gray 1958; Prosiński 1984; TAPPI 1996-1997). None of the methods used in the analysis of wood provides the quantitative separation of wood components, because of the existence of an ultrastructural and chemical association between the macromolecules of the cell wall. That is why it is difficult to achieve a sum close to $100 \%$ for all examined components. In the case of overlapping results, the sum of the components can be much higher than 100\% (Fengel and Wegener 1989; Prosiński 1984).

The content of chemical components was analysed in two parallel determinations as follows:

- moisture content, by a drying and weighing method at a temperature of $103 \pm 2{ }^{\circ} \mathrm{C}$ (Prosiński 1984);

- content of substances soluble in cold water, using extraction with distilled water at room temperature for a time of 48 h (Prosiński 1984; TAPPI 1996-1997);

- content of substances soluble in hot water, using extraction with distilled water at $100{ }^{\circ} \mathrm{C}$ for a time of $3 \mathrm{~h}$ (Prosiński 1984; TAPPI 1996-1997);

- content of extractives soluble in ethanol (95\%), $8 \mathrm{~h}$ in a Soxhlet apparatus (Browning 1967; Prosiński 1984);

- content of substances soluble in a hot $1 \%$ aqueous solution of sodium hydroxide (Prosiński 1984; TAPPI 1996-1997). The weak hot alkali solution extracts low molecular weight carbohydrates consisting mainly of hemicelluloses and degraded cellulose. A characteristic feature of hemicelluloses is solubility in alkali solutions. 
This determination is not equivalent to quantification of hemicelluloses, as some of it does not dissolve in alkaline solutions.

- cellulose content, by Seifert's method using acetyl acetone and dioxane (Browning 1967; Prosiński 1984);

- content of Klason lignin, insoluble in sulphuric acid, by the TAPPI method based on hydrolysis of the carbohydrate wood components with $72 \%$ sulphuric acid and quantitative determination of the remaining lignin (Prosiński 1984; TAPPI T 222 om-02 2002);

- content of lignin soluble in sulphuric acid, in the filtrate following determination of insoluble lignin, using UV spectrophotometry at a wavelength of $205 \mathrm{~nm}$ using a UNICAM UV/VIS model UV2 spectrometer (UK) (TAPPI UM 250 1991);

- pentosans content, using Tollens' method-hydrolysis of pentosans to furfural with a solution of hydrochloric acid, precipitation of furfural phloroglucide with phloroglucinol, and gravimetric determination of the quantity of that substance (Prosiński 1984). Pentosans are the main noncellulosic carbohydrates (hemicelluloses) of hardwoods;

- ash content—content of mineral substances remaining following complete burning of the wood at $575 \pm 25^{\circ} \mathrm{C}$ (Browning 1967; Prosiński 1984);

- $\mathrm{pH}$, using Gray's method-1 g pulverised wood is immersed in $5 \mathrm{ml}$ distilled water, and the $\mathrm{pH}$ is measured after $20 \mathrm{~min}$ (Gray 1958). The ORION 900A pH meter (USA) with $\mathrm{Ag} / \mathrm{AgCl}$ ORION Triode model 91-57 BIN was used.

The percentage contents of chemical components of birch wood were calculated in relation to oven-dried wood.

\section{Statistical analysis}

The influence of age on the chemical composition of wood of silver birch was analysed using the Kruskal-Wallis test, which is a nonparametric alternative to analysis of variance. This method was chosen because the data did not meet the homogeneity of variance criterion (result of Levene's test $p<0.001$ ), and in some of the analysed groups, the data were not normally distributed. When statistically significant differences between the analysed categories were found, a multiple range rank test was performed to identify groups having similar values of the analysed characteristics (Bruchwald 1989; Kala 2009).

Additionally, for trees of the same age, the significance of differences in the average values of features characterising the chemical structure of wood depending on the forest habitat type was examined. The analysis was performed using the $t$ test with the Cochran-Cox adjustment, due to the heterogeneity of variance in some of the compared groups (Cochran and Cox 1957). 


\section{Results and discussion}

\section{Results}

The 51 samples of birch wood obtained from 17 particular study sites constituted averaged material from six trees (two in each of the three thickness classes- the thinnest trees, moderately thick trees, and the thickest trees). The mean results for each sample are listed in Table 1. The subsequent Table 2 presents the average results of particular analyses for the age classes: 70, 50, and 30 years, taking into account the different locations, the two forest habitat types, and the three thickness classes of silver birch trees.

The content of substances soluble in cold water ranged from $0.14 \%$ in sample 14 (70 years) to $1.77 \%$ in sample 7 (50 years) (Table 1 ). The mean content of substances soluble in cold water for the whole of the analysed material was $0.60 \%$, with a minimum value of $0.13 \%$ and a maximum of $1.82 \%$ for single determinations (Table 2).

The content of substances soluble in hot water ranged from $0.86 \%$ in sample 3 (30 years) to $2.76 \%$ in sample 7 (50 years) (Table 1 ). For the whole of the analysed material, the mean content of substances soluble in hot water was $1.45 \%$ (2.4 times more than substances soluble in cold water), with a minimum value of $0.84 \%$ and a maximum of $2.77 \%$ for single determinations (Table 2).

Comparison of contents of substances soluble in cold and hot water between age classes showed an absence of statistically significant differences ( $p=0.44$ and $p=0.21$, respectively) between the analysed groups.

In contrast to the results presented here, studies of other tree species by different authors have shown an effect of tree age on the content of water-soluble substances (Glixelli and Prosiński 1951; Rencoret et al. 2011; Stolarski et al. 2011).

In the tested birch wood, contents of extractives soluble in ethanol ranged from $1.08 \%$ in sample 13 (50 years) to $2.57 \%$ in sample 4 (30 years) (Table 1 ). The mean content of these substances for the whole of the analysed material was $1.49 \%$, with a minimum value of $1.07 \%$ and a maximum of $2.61 \%$ for single determinations (Table 2).

Comparison of contents of substances soluble in ethanol between age classes showed an absence of statistically significant differences $(p=0.3334)$ between the analysed groups.

The effect of tree age on the content of extractives in wood has been the subject of many investigations. Some of them have shown a decrease and some have shown an increase in the content of extractives as the age of trees increased (Glixelli and Prosiński 1951; Miranda and Pereira 2002; Mohammadi et al. 2011; Morais and Pereira 2012; Rencoret et al. 2011; Stolarski et al. 2011; Waliszewska et al. 2015).

The contents of substances soluble in $1 \% \mathrm{NaOH}$ (hemicelluloses soluble in alkali) ranged from $13.18 \%$ in sample 6 (70 years) to $17.58 \%$ in sample 7 (50 years) (Table 1). The mean content for the whole of the analysed material was $14.87 \%$, with a minimum value of $12.81 \%$ and a maximum of $17.62 \%$ for single determinations (Table 2). 


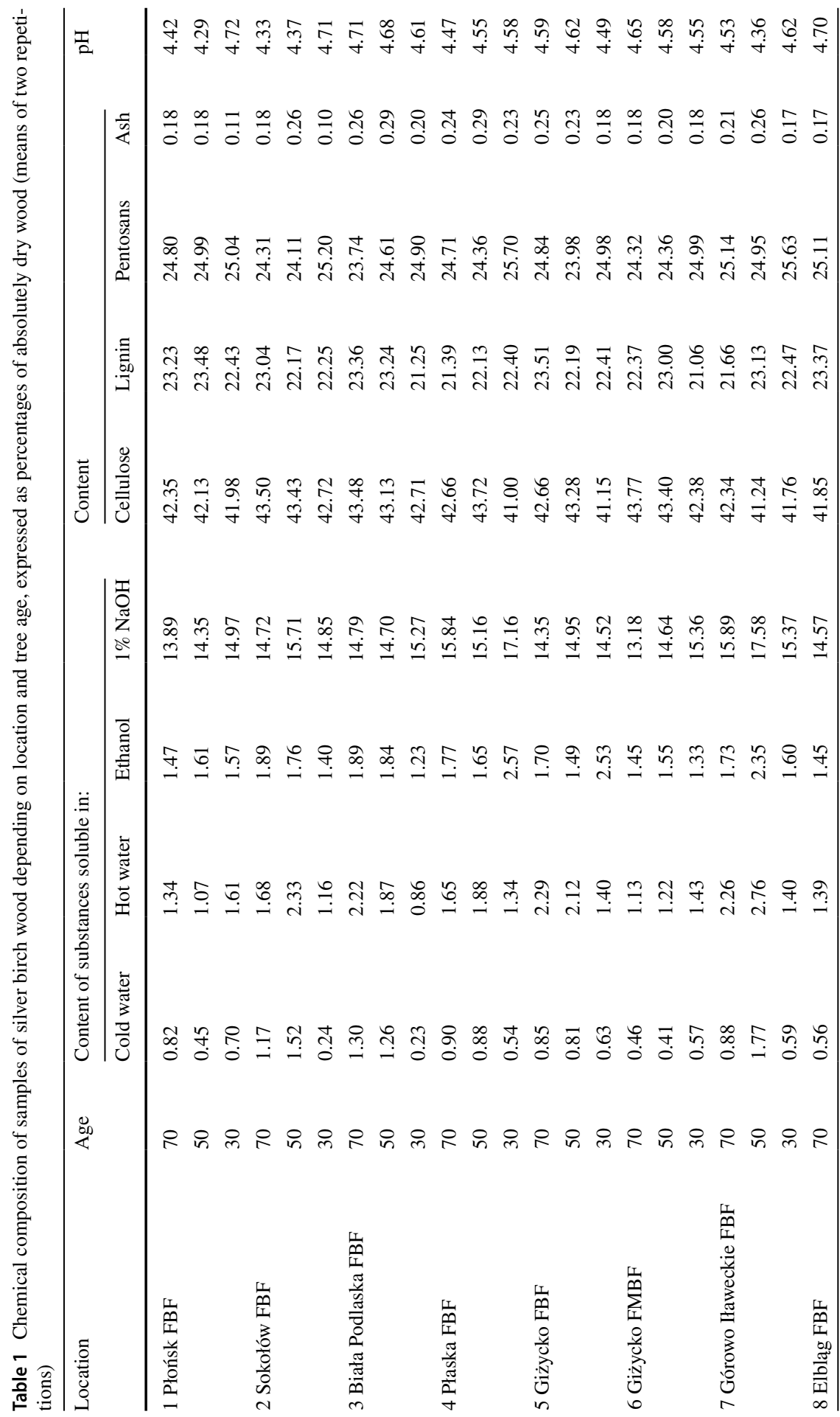




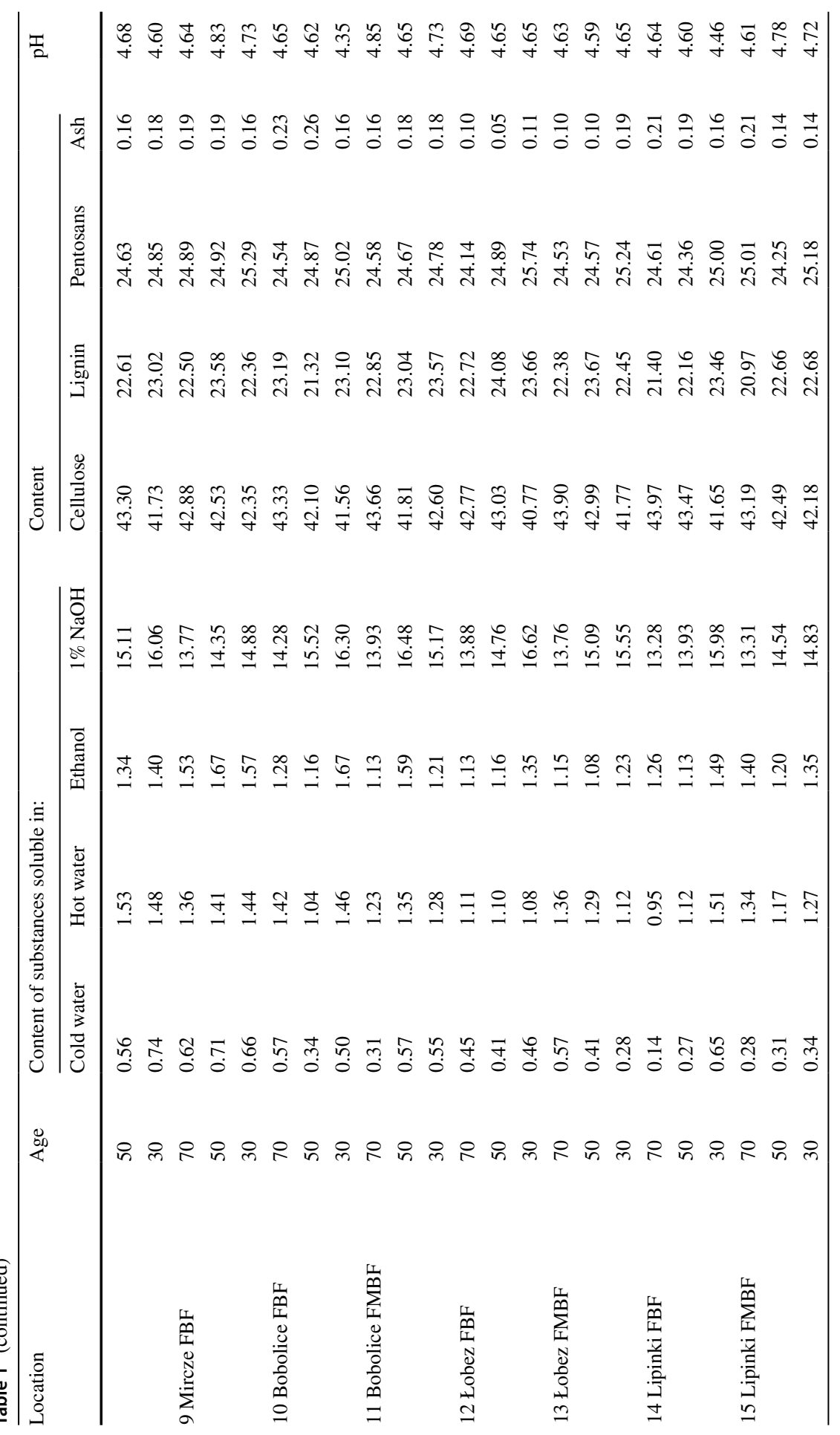




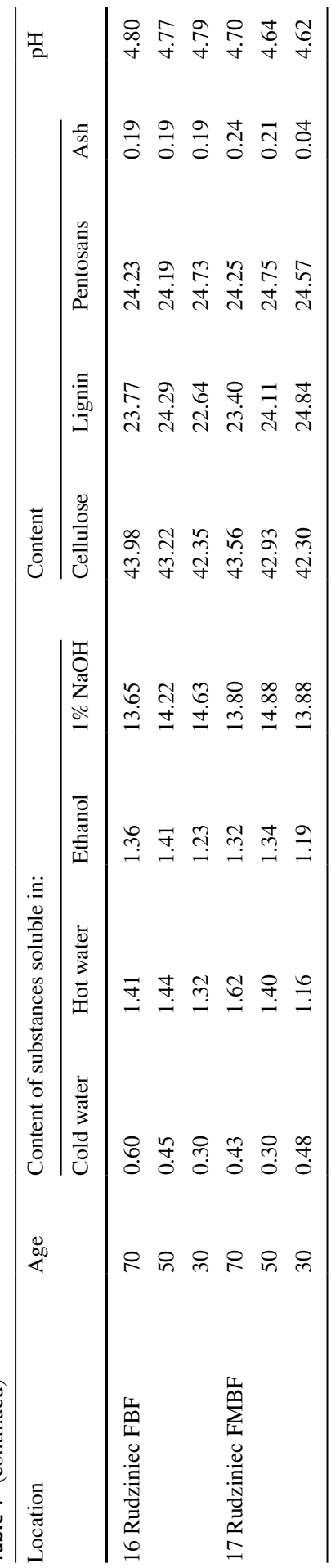




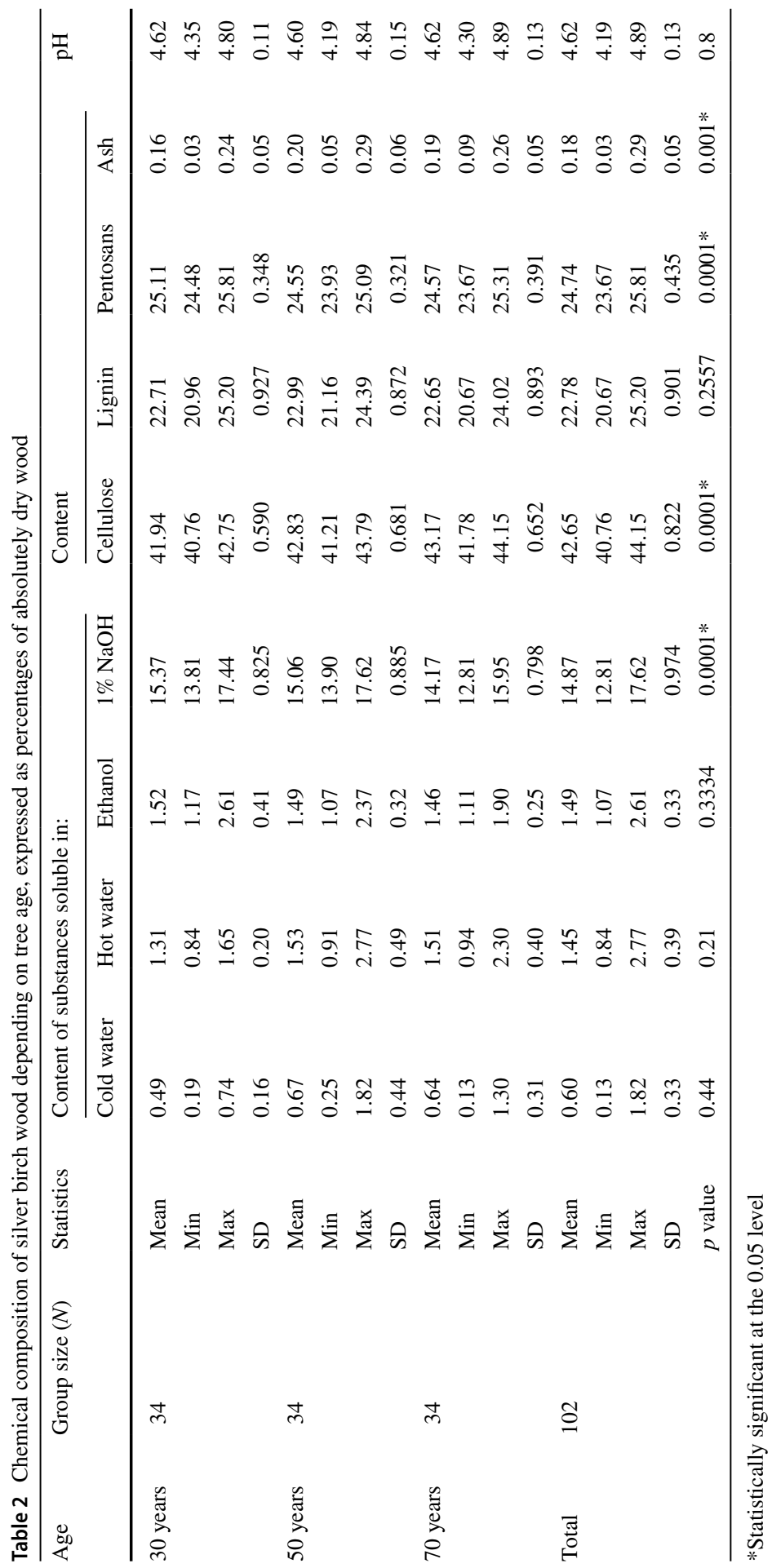


Comparison of contents of substances soluble in $1 \% \mathrm{NaOH}$ between age classes showed the existence of statistically significant differences $(p<0.0001)$. The lowest values were found in the oldest tree stands (70 years), where the content of substances soluble in $1 \% \mathrm{NaOH}$ differed statistically significantly from the other groups. No statistically significant differences were identified between the results obtained for the 30-year and 50-year age classes.

The content of pentosans in the analysed samples of birch wood ranged from $23.74 \%$ in sample 3 (70 years) to $25.74 \%$ in sample 12 (30 years) (Table 1). The mean content of pentosans for the whole of the analysed material was $24.74 \%$, with a minimum value of $23.67 \%$ and a maximum of $25.81 \%$ for single determinations (Table 2).

A comparison of the contents of pentosans between age classes showed the existence of statistically significant differences $(p<0.0001)$. The largest values were recorded for the youngest tree stands (30 years), where the pentosans content differed statistically significantly from the other groups. No statistically significant differences were identified between the results obtained for the 50-year and 70-year age classes.

The maximum content of the main component of wood-cellulose (determined by Seifert's method) - in the analysed samples of birch wood was $43.98 \%$ in sample 16 (70 years), and the minimum cellulose content was $40.77 \%$ in sample 12 (30 years) (Table 1). The mean content of cellulose for the whole of the analysed material was $42.65 \%$, with a minimum value of $40.76 \%$ and a maximum of $44.15 \%$ for single determinations (Table 2).

Comparison of contents of cellulose between age classes showed statistically significant differences $(p<0.0001)$. The lowest values were found in the case of the youngest tree stands (30 years), where the cellulose content differed statistically significantly from the other groups. No statistically significant differences were identified between the results obtained for the 50-year and 70-year age classes.

A higher content of cellulose in older trees compared with younger trees of the same species was reported by Glixelli and Prosiński (1951), Guidi et al. (2009), Mohammadi et al. (2011), Rencoret et al. (2011), Stolarski et al. (2011), Uprichard and Lloyd (1980), Waliszewska et al. (2015) and Wróblewska et al. (2009). An exception to this rule was presented by Prądzyński et al. (1994) and Prosiński et al. (1955).

The total content of acid-soluble and acid-insoluble lignin ranged from $20.97 \%$ in sample 15 ( 70 years) to $24.84 \%$ in sample 17 (30 years) (Table 1). For the whole of the analysed material, the mean total lignin content was $22.78 \%$, with a minimum value of $20.67 \%$ and a maximum of $25.20 \%$ for single determinations (Table 2).

The mean contents of lignin insoluble in sulphuric acid in the three analysed age classes were $18.83 \%$ (30 years), $18.81 \%$ (50 years), and $18.70 \%$ (70 years). The contents of soluble lignin were $3.88 \%, 4.17 \%$, and $3.95 \%$, respectively.

Comparison of lignin contents between age classes showed an absence of statistically significant differences $(p=0.2557)$ between the analysed groups.

Other authors have revealed that in some species, older trees contained more lignin than younger ones, although in some studies, the reverse was found to be the case (Glixelli and Prosiński 1951; Guidi et al. 2009; Miranda and Pereira 2002; 
Mohammadi et al. 2011; Prądzyński et al. 1994; Rencoret et al. 2011; Stolarski et al. 2011; Uprichard and Lloyd 1980; Waliszewska et al. 2015; Wróblewska et al. 2009).

The content of ash (mineral substances) took a minimum value of $0.04 \%$ in sample 17 (30 years) and a maximum of $0.29 \%$ in sample 4 (50 years) (Table 1). For the whole of the analysed material, the mean ash content was $0.18 \%$, with a minimum value of $0.03 \%$ and a maximum of $0.29 \%$ for single determinations (Table 2).

Comparison of ash contents between age classes showed statistically significant differences $(p=0.001)$. The lowest values were recorded for the youngest tree stands (30 years), where the ash content differed statistically significantly from the other groups. No statistically significant differences were identified between the results obtained for the 50-year and 70-year age classes.

The results presented here as well as data from the literature show that the ash content in different species of wood depends on the age of the tree. In silver birch (Betula pendula Roth.) trees aged 30, 50, and 70 years, the amount of mineral substances (ash) increased with the age of the trees. Opposite results-the younger the tree, the higher the content of mineral substances-were observed in E. globulus (Rencoret et al. 2011), Eucalyptus camledulnnesis (Mohammadi et al. 2011), and in spruce, pine, and fir wood (Glixelli and Prosiński 1951; Prosiński et al. 1955).

The analysed samples of birch wood were acidic, with $\mathrm{pH}$ ranging from 4.29 for sample 1 (30 years) to 4.85 for sample 11 ( 70 years) (Table 1 ). The mean $\mathrm{pH}$ for the whole of the analysed material was 4.62 , with a minimum value of 4.19 and a maximum of 4.89 for single determinations (Table 2).

Comparison of $\mathrm{pH}$ between age classes showed an absence of statistically significant differences $(p=0.8)$ between the analysed groups.

More than 100 different species of wood have $\mathrm{pH}$ values between 4.0 and 6.0, and one of them is birch. Packman (1960) and Dietrichs (1972) reported for birch wood a $\mathrm{pH}$ value of 4.60, Wróblewska and Zieliński (1994) reported for silver birch a pH value of 4.4, while Fengel and Wegener (1989) and Wagenführ and Scheiber (2007) gave 4.8. The acidity of wood, among others, is of practical importance in the manufacture of composite wood products, especially particle boards and MDF. It affects the gelling and hardening of resins used for gluing boards, the susceptibility of chips to glue, as well as the emission of formaldehyde (Frąckowiak 1999; Johns and Niazi 1980; Zenkteler 1979).

Table 3 presents average values of components characterising the chemical structure of birch wood for wood aged 30, 50, and 70 years, depending on the forest habitat type. A significant effect of forest habitat type was found only for 30-year-old trees in the case of cellulose and ethanol-soluble substances. It is important to note the low standard deviation for cellulose in 30-year-old trees; within forest habitat types, the mean values of this component for particular locations were very close to each other.

The influence of the age of trees from two different forest habitat types-fresh broadleaved forest (FBF) and fresh mixed broadleaved forest (FMBF) - on the content of main components and soluble substances of silver birch wood is presented in Figs. 2 and 3.

The sum of the contents of the main components of wood-cellulose, lignin, and pentosans (hemicelluloses) — did not show any significant differences between the 


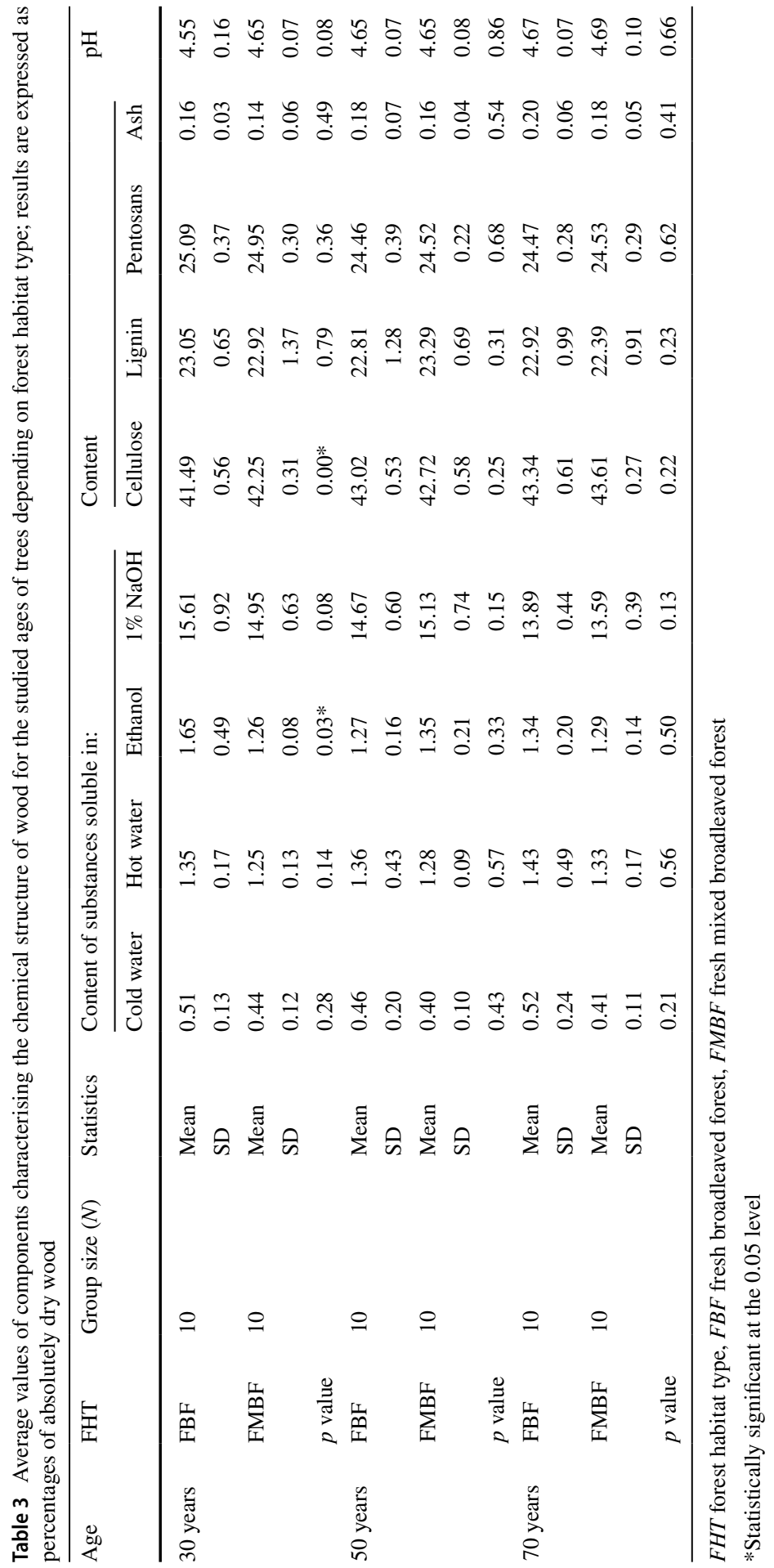




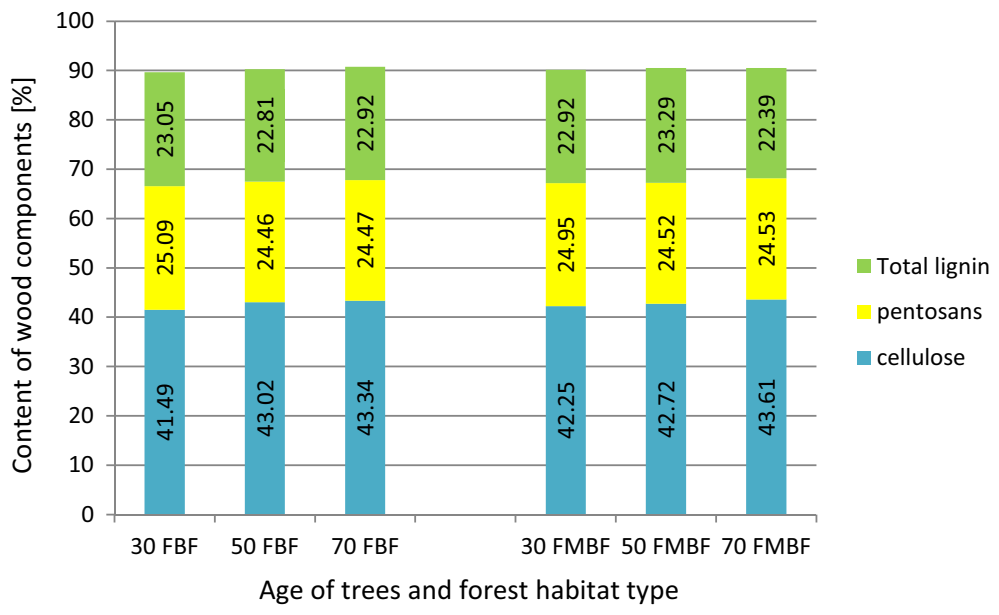

Fig. 2 Content of main components of silver birch wood depending on tree age and forest habitat type: fresh broadleaved forest (FBF) and fresh mixed broadleaved forest (FMBF)

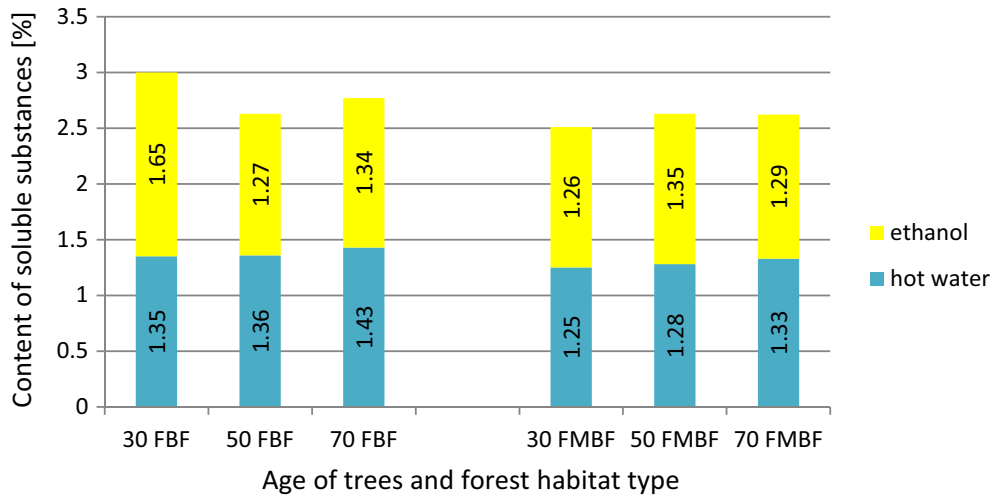

Fig. 3 Content of water and ethanol-soluble extractives in silver birch wood depending on tree age and forest habitat type: fresh broadleaved forest (FBF) and fresh mixed broadleaved forest (FMBF)

forest habitat types and ages of trees (Fig. 2). The total content of substances extracted with water and ethanol was higher in particular age groups for birch wood from FBF in relation to wood from FMBF (Fig. 3). For 70-year-old trees from FBF, it was 2.77\% compared with $2.62 \%$ from FMBF; for 50-year-old trees, the same value of $2.63 \%$ was recorded from both FBF and FMBF; and for 30-year-old trees, the value was 3.00\% from FBF compared with $2.51 \%$ from FMBF. 


\section{Discussion}

The limited literature reports on the influence of the age of birch trees on the chemical composition of its wood prompted us to extend the discussion using the results obtained for other species of wood.

Rencoret et al. (2011) studied the wood of clones from a plantation of eucalyptus (E. globulus) at ages of 1 month, 18 months, and 9 years and observed an increase in the content of crystalline cellulose and acid-soluble and acid-insoluble lignin, along with a decrease in the content of extractives, water-soluble substances, and ash. They reported that as the eucalyptus matures, not only does the lignin content increase, but there is also a change in its chemical structure. Uprichard and Lloyd (1980) studied older specimens of radiata pine with ages of 25 and 50 years and found the content of extractives to be higher in 50-year-old than in 25-year-old trees. The older radiata pine trees also contained more cellulose and less lignin.

In the wood of basket willow shoots aged from 1 to 6 years, it was found that the lignin content increased, and the cellulose content decreased, with increasing age (Prądzyński et al. 1994). Other authors have reported that the younger wood of both broadleaf and coniferous species contains less cellulose, lignin, and hemicellulose than the wood of older trees (Guidi et al. 2009; Rowel et al. 1997; Wróblewska et al. 2009).

In studies on the chemical composition of wood from 1-, 2-, and 3-year-old shoots of five new willow varieties, Stolarski et al. (2011) found that the older shoots had a statistically significantly greater content of cellulose (by 4-5\%), and lower contents of lignin (by 1-3.3\%), pentosans (by 0.5-1\%), hemicellulose (by 4-7.5\%), substances soluble in cold water (by 2-2.5\%), substances soluble in hot water (by $2-4.5 \%$ ), and extractives (by 1-2\%).

Glixelli and Prosiński (1951) studied the wood of spruce aged between 37 and 81 years, pine between 27 and 150 years, and fir between 25 and 80 years, and found with increasing age a decrease in the contents of ash, substances soluble in cold and hot water, in an ethanol-benzene mixture and in $1 \% \mathrm{NaOH}$, together with a rise in contents of lignin, cellulose, and pentosans. Prosiński et al. (1955) studied samples of spruce wood collected $2 \mathrm{~m}$ above ground from trees aged 38, 52, 60, and 75 years, growing in different regions of Poland. They showed that the ash content in spruce wood depended on the age of the tree (the younger the tree, the higher the content of mineral substances). They did not find any impact of age on the contents of cellulose and lignin in the studied wood. This was probably related to the larger number of variables influencing the content of these components, such as the soil quality and the forest habitat type.

Miranda and Pereira (2002) reported an increase in the content of extractives and lignin, and a fall in the content of polysaccharides, with increasing age of trees of $E$. globulus from 2 to 6 years. Morais and Pereira (2012) reported a higher content of extractives in trees of E. globulus, which had reached felling age (18 years).

Examination of chemical composition of Eucalyptus camledulnnesis at the age of 6,8 , and 10 years showed that the amount of cellulose and its degree of polymerisation, as well as contents of lignin and extractives, increased as the age of the trees 
increased, but the amount of hemicellulose and ash decreased (Mohammadi et al. 2011).

The cited research by the above-mentioned authors confirms the impact of tree age on the content of structural compounds and extractives in wood. The results reported in the literature refer to specific studies and tree growing conditions, as well as their age, species, and the parts of the tree from which samples are taken (Bao et al. 2001; Cown and McConchie 1982; Dietrichs 1972; Han and Rowell 1997; Hytönen and Nurmi 2015; Miranda et al. 2017; Mohammadi et al. 2011; Morais and Pereira 2012; Piispanen and Saranpää 2001; Rencoret et al. 2011; Uprichard and Lloyd 1980; Waliszewska et al. 2015). These results cannot be generalised, and it is not possible to formulate on their basis a general rule for the dependence of the chemical composition of wood on tree age for all species and for the entire range of ages, from young saplings to 100-year-old trees.

In all of the reported studies, only the contents of substances soluble in cold and hot water were higher in young trees and lower in older trees. Another common finding was the increase in cellulose content as trees develop, but even here, exceptions have been noted (Prądzyński et al. 1994; Prosiński et al. 1955). The literature shows that the impact of the age of trees on lignin content in wood is not distinct. According to some researchers, the content of lignin in wood increases with the age of trees (Glixelli and Prosiński 1951; Guidi et al. 2009; Miranda and Pereira 2002; Mohammadi et al. 2011; Prądzyński et al. 1994; Rencoret et al. 2011; Rowel et al. 1997; Wróblewska et al. 2009), and according to others, it decreases (Healey et al. 2016; Stolarski et al. 2011; Uprichard and Lloyd 1980; Zobel and Sprague 1998). One may sum up similarly the effect of tree age on the contents of extractives, pentosans, ash, and substances soluble in $1 \% \mathrm{NaOH}$. This variability in the results may be ascribed to various other factors affecting the growth and condition of trees, including the species, weather conditions, soil quality, forest habitat type, whether the wood came from a plantation or a natural forest, and even differences in the age of the trees studied (very young and much older), the part of the tree from which samples were taken, the time of sampling, etc.

In the studies carried out at the Wood Technology Institute, the observations of other authors have been confirmed only in relation to cellulose (Glixelli and Prosiński 1951; Mohammadi et al. 2011; Rencoret et al. 2011; Stolarski et al. 2011; Uprichard and Lloyd 1980; Waliszewska et al. 2015). The mean content of cellulose in samples of birch wood collected from all 17 sites was lowest in the youngest trees (30 years). In the case of lignin, the mean content was almost identical in all age groups, lying between 22.65 and $22.99 \%$. The mean contents of pentosans (hemicelluloses) and substances soluble in $1 \% \mathrm{NaOH}$ (alkali-soluble hemicelluloses) were highest in the wood of the youngest trees, being $25.11 \%$ and $15.37 \%$, respectively. The position was reversed as regards the contents of substances soluble in cold and hot water, which were found to be lowest $(0.49 \%$ and $1.31 \%$, respectively) in the youngest (30-year-old) trees. This group was also found to have the lowest mean ash content: $0.16 \%$, compared with $0.20 \%$ in the 50 -year-old trees and $0.19 \%$ in the 70 -year-old trees. The average content of extractives (substances extracted with ethanol) was almost identical, at around $1.5 \%$, in birches of all age classes. The studied wood samples were found to be acidic: the mean $\mathrm{pH}$ for all age groups was 4.62. 


\section{Conclusion}

From the analysis of the results obtained for the chemical structure of silver birch wood depending on the age of the tree, the following conclusions can be drawn:

1. Tree age was shown to have a statistically significant effect on the contents of cellulose, pentosans, ash, and substances soluble in $1 \% \mathrm{NaOH}$.

2. Tree age was found to have no statistically significant effect on the content of lignin, substances soluble in cold and hot water, and substances soluble in ethanol in the wood of silver birch. There was also no statistically significant influence of the age of the trees $(30,50$, and 70 years) on the $\mathrm{pH}$ (acidity) of silver birch wood.

3. Cellulose content was lowest in 30-year-old tree stands, and rose as the age of the trees increased. A similar pattern was obtained for ash content, which was also lowest in the youngest of the studied trees (30 years).

4. The contents of pentosans and substances soluble in $1 \% \mathrm{NaOH}$ (hemicellulose) were highest in the wood of the youngest trees (30 years) and lowest in the wood of the oldest trees ( 70 years).

5. Due to the higher cellulose content, producers of cellulose, paper and fibreboard can use wood aged between 50 and 70 years. However, wood of this age, with higher technical quality, is currently bought by the plywood, sawmill and veneer industries. Therefore, the cellulose and fibreboard industry can use birch raw material of 50-70 years of age but of lower quality, with more wood defects.

6. Wood at age 30 with a lower content of minerals, the presence of which causes the blunting of tools and hinders processing during drilling, milling, sawing, and grinding, should potentially be favoured more by the wood-based panel industry.

7. Wood from FMBF at age 30 is potentially more suitable for the pulp and paper and fibreboard industries, due to its higher cellulose content.

Acknowledgements This work was supported by the General Directorate of State Forests in Poland (Grant Number EO-2717-13/13).

Open Access This article is distributed under the terms of the Creative Commons Attribution 4.0 International License (http://creativecommons.org/licenses/by/4.0/), which permits unrestricted use, distribution, and reproduction in any medium, provided you give appropriate credit to the original author(s) and the source, provide a link to the Creative Commons license, and indicate if changes were made.

\section{References}

Bao FC, Jiang ZH, Lu XX, Luo XQ, Zhang SY (2001) Differences in wood properties between juvenile wood and mature wood in 10 species grown in China. Wood Sci Technol 35:363-375. https://doi. org/10.1007/s002260100099

Berrocal A, Baeza J, Rodríguez J, Espinosa M, Freer J (2004) Effect of tree age on variation of Pinus radiata D. Don chemical composition. J Chil Chem Soc 49(3):251-256. https://doi.org/10.4067/ S0717-97072004000300012 
Bikovens O, Roze L, Pranovich A, Reunanen M, Telysheva G (2013) Chemical composition of lipophilic extractives from grey alder (Alnus incana). BioResources 8(1):350-357. http://ojs.cnr.ncsu. edu/index.php/BioRes/article/view/BioRes_08_1_350_Bikovens_Lipophilic_Extractives_Alder. Accessed 31 Aug 2018

Browning BL (1967) Methods of wood chemistry. Wiley, New York

Bruchwald A (1989) Statystyka matematyczna dla leśników. (Mathematical statistics for foresters). SGGW, Warsaw

Cochran WG, Cox GM (1957) Experimental designs, 2nd edn. Wiley, New York

Cown DJ, McConchie DL (1982) Rotation age and silvicultural effects on wood properties of four stands of Pinus radiata. N Z J For Sci 12(1):71-78

Dietrichs HH (1972) Zum chemischen Verhalten von Nutzhölzern. (On the chemical behavior of timber). Holz Zentralbl. 98(108):1522-1525

Fabisiak E (2005) Zmienność podstawowych elementów anatomicznych i gęstości drewna wybranych gatunków drzew (Variation of fundamental anatomical elements and wood density of selected tree species). Wyd. AR w Poznaniu. Rozprawy Naukowe 369

Fengel D, Grosser D (1975) Chemische Zusammensetzung von Nadel-und Laubhölzern. (Chemical composition of softwoods and hardwoods). Holz Roh Werkst 33:32-34

Fengel D, Wegener G (1989) Wood-chemistry, ultrastructure, reactions. Walter de Gruyter, Berlin

Fidelis CHV, Sampaio PTB, Krainovic PM, Augusto F, Barata LES (2013) Correlation between maturity of tree and $\mathrm{GC} \times \mathrm{GC}-\mathrm{qMS}$ chemical profiles of Essentials oil from leaves of Aniba rosaeodora Ducke. Microchem J 109:73-77. https://doi.org/10.1016/j.microc.2012.03.034

Frąckowiak I (1999) Pojemność buforowa drewna w technologiach płyt wiórowych (Summary: wood buffer capacity in chipboards technology). Prace Inst Technol Drewna 43(1/2):4-44

Galewski W, Korzeniowski A (1958) Atlas najważniejszych gatunków drewna (Atlas of the most important wood types). PWRiL, Warsaw

Glixelli S, Prosiński S (1951) Z badań nad składem chemicznym drewna niektórych drzew krajowych (Research on the chemical composition of wood of some national trees). Poznańskie Towarzystwo Przyjaciół Nauk Wydział Matematyczno Przyrodniczy, Prace Komisji Matematyczno-Przyrodniczej, Poznań. Tom VI Zeszyt 12:259-266

Graves HS (1906) Forest mensuration. Wiley, New York

Gray VR (1958) The acidity of wood. J Inst Wood Sci 1:58-64

Grochowski J (1973) Dendrometria. PWRiL, Warsaw

Guidi W, Tozzini C, Bonari E (2009) Estimation of chemical traits in poplar short-rotation coppice at stand level. Biomass Bioenergy 33:1703-1709

GUS (Central Statistical Office) (2017) Leśnictwo (Forestry) 2017. https://stat.gov.pl/obszary-tematyczne /rolnictwo-lesnictwo/lesnictwo/lesnictwo-2017,1,13.html. Accessed 31 July 2018

Han JS, Rowell JS (1997) Chemical composition of fibers. In: Rowell RM, Young RA, Rowell JK (eds) Paper and composites from agro-based resources. LEWIS Publishers, Boca Raton, pp 83-134

Healey AL, Lupoi JS, Lee DJ, Sykes RW, Guenther JM, Tran K, Decker SR, Singh S, Simmon BA, Henry RJ (2016) Effect of aging on lignin content, composition and enzymatic saccharification in Corymbia hybrids and parental taxa between years 9 and 12. Biomass Bioenergy 93(2016):50-59

Helińska-Raczkowska L, Fabisiak E (1995) Duration of the juvenile period in diameter growth of birch (Betula pendula Roth.) trees. Sylwan 12:77-84

Hytönen J, Nurmi J (2015) Heating value and ash content of intensively managed stands. Wood Res 60(1):71-82

Johns WE, Niazi KA (1980) Effect of pH and buffering capacity of wood on the gelation time of ureaformaldehyde resin. Wood Fiber 12(4):255-263

Kala R (2009) Statystyka dla przyrodników (Statistics for naturalists). Wydawnictwo Uniwersytetu Przyrodniczego w Poznaniu, Poznan

Karnaouri A, Rova U, Christakopoulos P (2016) Effect of different pretreatment methods on birch outer bark: new biorefinery routes. Molecules 21(4):427. https://doi.org/10.3390/molecules21040427

Lachowicz H (2010a) Structure of silver birch wood fibers (Betula pendula Roth.) in north-eastern Poland. Leśne Prace Badawcze 71(1):39-50. https://doi.org/10.2478/v10111-010-0002-5

Lachowicz H (2010b) Selected indicators of technical quality of silver birch (Betula pendula Roth.) wood in north-eastern Poland. Leśne Prace Badawcze 71(2):135-147. https://doi.org/10.2478/v1011 1-010-0010-5

Lachowicz H (2011a) Influence of location and age on the value of wood strength coefficients for silver birch (Betula pendula Roth.). Sylwan 155(8):535-545 
Lachowicz H (2011b) Effect of tree thickness on the selected structural and physico-mechanical properties of silver birch (Betula pendula Roth.) wood. Sylwan 155(9):581-588

Lachowicz H (2015) Wieloczynnikowa analiza zmienności wybranych właściwości strukturalnych, fizycznych i mechanicznych drewna brzozy brodawkowatej (Betula pendula Roth.) (Multivariate analysis of the variation of structural, physical and mechanical properties of silver birch (Betula pendula Roth.) wood). Rozprawy Naukowe i Monografie. Wydawnictwo SGGW, Warsaw

Lachowicz H, Paschalis-Jakubowicz P (2011) Variability of the wood fibre structure indices for silver birch (Betula pendula Roth.) in north-eastern Poland. Sylwan 155(7):446-458

Lachowicz H, Paschalis-Jakubowicz P, Wojtan R (2018a) Multivariate analysis of the variability in the density of oven-dry wood of silver birch (Betula pendula Roth) in Poland. Drewno 61:201. https:// doi.org/10.12841/wood.1644-3985.233.09

Lachowicz H, Sajdak M, Paschalis-Jakubowicz P, Cichy W, Wojtan R, Witczak M (2018b) The influence of location, tree age and forest habitat type on basic fuel properties of the wood of the silver birch (Betula pendula Roth.) in Poland. Bioenergy Res 11(3):638-651. https://doi.org/10.1007/s1215 5-018-9926-z

Lachowicz H, Bieniasz A, Wojtan R (2019a) Variability in the basic density of silver birch wood in Poland. Silva Fenn 53(1):13. https://doi.org/10.14214/sf.9968

Lachowicz H, Wróblewska H, Sajdak M, Komorowicz M, Wojtan R (2019b) The chemical composition of silver birch (Betula pendula Roth.) wood in Poland depending on forest stand location and forest habitat type. Cellulose. https://doi.org/10.1007/s10570-019-02306-2

Miranda I, Pereira H (2002) The variation of chemical composition and pulping yield with age and growth factors in young Eucalyptus globulus. Wood Fiber Sci 34(I):140-145

Miranda I, Sousa V, Ferreira J, Pereira H (2017) Chemical characterization and extractives composition of heartwood and sapwood from Quercus faginea. PLoS ONE 12(6):e0179268. https://doi. org/10.1371/journal.pone.0179268

Mohammadi NS, Nemati M, Samariha A, Tabei A, Ravanbakhsh F, Kiaei M (2011) Studying the effect of the age of a tree on chemical composition and degree of polymerization cellulose. Indian $\mathrm{J}$ Sci Technol 4(12):1679-1680

Morais MC, Pereira H (2012) Variation of extractives content in heartwood and sapwood of Eucalyptus globulus trees. Wood Sci Technol 46:709-719. https://doi.org/10.1007/s00226-011-0438-7

Nikitin NI (1962) Chimija drewiesiny i celljulozy (Chemistry of wood and cellulose). Leningrad, Moscow, pp 512-513

Nurmi J (1997) Heating values of mature trees. Acta For Fenn 256:1-28

Packman DF (1960) The acidity of wood. Holzforschung 14(6):178-183

Pietarinen SP, Willför SM, Ahotupa MO, Hemming JE, Holmbom BR (2006) Knotwood and bark extracts: strong antioxidants from waste materials. J Wood Sci 52:436-444. https://doi.org/10.1007/ s10086-005-0780-1

Piispanen R, Saranpää P (2001) Variation of non-structural carbohydrates in silver birch (Betula pendula Roth) wood. Trees 15(7):444-451. https://doi.org/10.1007/s004680100125

Prądzyński W, Brzozowska K, Bukowski R (1994) Development and chemical composition of osiers (Salix spp.) growing along the Polish highway A-2. In: III Krajowe Sympozjum "Reakcje biologiczne drzew na zanieczyszczenia przemysłowe, Kórnik

Prosiński S (1954) Z badań nad wyodrębnianiem masy celulozowej z drewna topoli czarnej i białej (Research on the isolation of pulp from wood of black and white poplar). Biuletyn Instytutu Technologii Drewna Nr 2:229-238

Prosiński S (1984) Chemia drewna (Wood chemistry). PWRiL, Warsaw

Prosiński S, Kontek W, Babicki R (1955) Skład chemiczny drewna świerkowego w zależności od wieku drzew i zasięgu naturalnego (The influence of the natural range of distribution of spruce and its age on the chemical composition of wood). Prace Instytutu Technologii Drewna Rok I Z 1:5-22

Rencoret J, Gutierrez A, Nieto L, Jimenez-Barbero J, Faulds CB, Kim H, Ralph J, Martinez AT, del Rio JC (2011) Lignin composition and structure in young versus adult Eucalyptus globulus plants. Plant Physiol 155:667-682. https://doi.org/10.1104/pp.110.167254

Roitto M, Siwale W, Tanner J, Ilvesniemi H, Julkunen-Tiitto R, Verkasalo E (2015) Characterization of extractives in tree biomass and by-products of plywood and saw mills from Finnish birch in different climatic regions for value-added chemical products. In: 5th International scientific conference on hardwood processing 2015, international academy of wood science-annual meeting, Sept. 15-17, 2015, Quebec City, Canada, Proceedings. pp 174-181 
Routa J, Brännström H, Anttila P, Mäkinen M, Jänis J, Asikainen A (2017) Wood extractives of Finnish pine, spruce and birch - availability and optimal sources of compounds. A literature review. Natural Resources Institute Finland (Luke), Helsinki

Rowel RM, Han JS, Bisen SS (1997) Changes in fiber properties during the growing season. In: Rowell RM, Young RA, Rowell JK (eds) Paper and composites from agro-based resources. LEWIS Publishers, Boca Raton, pp 23-37

Royer M, Houde R, Viano Y, Stevanovic T (2012) Non-wood forest products based on extractives-a new opportunity for the Canadian forest industry part 1: hardwood forest species. J Food Res. https://doi. org/10.5539/jfr.v1n3p8

Stolarski MJ, Szczukowski S, Tworkowski J, Wróblewska H, Krzyżaniak M (2011) Short rotation willow coppice biomass as an industrial and energy feedstock. Ind Crops Prod 33:217-223. https://doi. org/10.1016/j.indcrop.2010.10.013

Surmiński J (1964) Skład chemiczny tkanek patologicznych drzewnych narośli rakowatych (Chemical composition of pathological tissues of wood carcinogenic growths). Rocznik Dendrologiczny XVIII:63-77

Szczepkowski A, Nicewicz D, Koczon P (2007) The relationship between tree health and chemical composition of beech (Fagus sylvatica L.) and oak (Quercus robur L.) wood of Polish provenances. Acta Sci Pol Silv Colendar Rat Ind Lignar 6(3):77-88

TAPPI (1996) Test methods (1996-1997). Tappi Press, Atlanta

TAPPI T 222 om-02 (2002) Acid-insoluble lignin in wood and pulp, in: 2002-2003 TAPPI Test Methods, 2002, Tappi Press, Atlanta, GA, USA

TAPPI UM 250 (1991) Acid-soluble lignin in wood and pulp. In: 1991 TAPPI useful methods, 1991, Tappi, Atlanta, GA, USA

Testova L, Vilonen K, Pynnönen H, Tenkanen M, Sixta H (2009) Isolation of hemicelluloses from birch wood: distribution of wood components and preliminary trials in dehydration of hemicelluloses. Lenzing Ber 87:58-65

Tullus A, Sellin A, Kupper P, Lutter R, Pärn L, Jasińska AK, Alber M, Kukk M, Tullus T, Tullus H, Lŏhmus K, Sŏber A (2014) Increasing humidity-a climate trend predicted for northern latitudes-alters the chemical composition of stemwood in silver birch and hybrid aspen. Silva Fenn 48(4):1-16

Uprichard JM, Lloyd JA (1980) Influence of tree age on the chemical composition of Radiata pine. N Z J For Sci 10(3):551-557

Voipio R, Laakso T (1992) Pienikokoisten puiden maanpäällisen biomassa kemiallinen koostumus. Summary: chemical composition of the above ground biomass of small-sized trees. Folia Forestalia 789:1-22

Wagenführ R, Scheiber C (2007) Holzatlas. (Wood atlas). VEB Fachbuchverlag, Leipzig

Waliszewska B, Prądzyński W, Zborowska M, Stachowiak-Wencek A, Waliszewska H, Spek-Dźwigała A (2015) The diversification of chemical composition of pine wood depending on the tree age. Ann Wars Univ Life Dciences SGGW For Wood Technol No 91:182-187

Wanin S (1953) Nauka o drewnie (Science of wood). PWRiL, Warsaw

Wolski J (1969) Pierśnica —reprezentatywną cechą do wyboru drzew próbnych przy oznaczaniu fizycznych i mechanicznych właściwości drewna (Diameter at breast height - a representative characteristic for the selection of sample trees to determine physical and mechanical wood properties in trees of stands studied). Sylwan 113(8):77-78

Wróblewska H, Zieliński MH (1994) Biodelignifikacja drewna pod wpływem działania grzybów rozkładu białego (Biodelignification of wood under the influence of white rot fungi). Instytut Technologii Drewna, Poznan

Wróblewska H, Komorowicz M, Pawłowski J, Cichy W (2009) Chemical and energetical properties of selected lignocellulosic raw material. Folia For Pol Ser B 40:67-78

Zenkteler M (1979) Praktyczne znaczenie chemicznego odczynu drewna (Summery: Practical meaning of the chemical reaction of wood). Przem Drzew 4:24-25

Zobel BJ, Sprague JR (1998) Juvenile wood in forest trees. Springer, Berlin

Publisher's Note Springer Nature remains neutral with regard to jurisdictional claims in published maps and institutional affiliations. 